\title{
HOXC10 Gene
}

National Cancer Institute

\section{Source}

National Cancer Institute. HOXC10 Gene. NCI Thesaurus. Code C116302.

This gene is involved in embryonic pattern formation. 